\title{
ROLE OF TOOL ROTATIONAL SPEED IN INFLUENCING MICROSTRUCTURAL EVOLUTION, RESIDUAL-STRESS FORMATION AND TENSILE PROPERTIES OF FRICTION-STIR WELDED AZ80A Mg ALLOY
}

\author{
VPLIV HITROSTI VRTENJA ORODJA NA RAZVOJ \\ MIKROSTRUKTURE, NASTANEK ZAOSTALIH NAPETOSTI IN \\ NATEZNO TRDNOST VRTILNO-TORNO VARJENE Mg ZLITINE \\ AZ80A
}

\author{
Pandian Sevvel $^{1}$, Chidambaram Satheesh ${ }^{2}$ \\ 1S.A. Engineering College, Department of Mechanical Engineering, Chennai - 600 077, Tamilnadu, India \\ ${ }^{2}$ Madha Institute of Engineering and Technology, Department of Mechanical Engineering, Chennai - 600122, Tamilnadu, India \\ drsevvel@saec.ac.in \\ Prejem rokopisa - received: 2017-12-08; sprejem za objavo - accepted for publication: 2018-04-26
}

doi:10.17222/mit.2017.213

\begin{abstract}
Joining flat plates of the AZ80A Mg alloy was carried out using the friction-stir-welding technique, employing various speeds of rotation (the tool), and it was observed that an M-shaped distribution characterizes the stress (residual) distributed in the longitudinal direction. Apart from this, the longitudinal stress (tensile) on the advancing side (AS) was found to be larger than that on the retreating side (RS) in the stir zone. It was experimentally recorded that there seem to be a slight increase in the stress values (tensile longitudinal residual), an increase in the tool rotational speed, and an increase in the peak tensile longitudinal stresses at the edge of the shoulder on the AS of the joints. The grain structures in the stir zone were also found to be influenced by the speed of the tool. Observations of fracture surfaces indicated that dimples and ridges resulted in a ductile fracture and quasi-cleavage resulted in a brittle fracture.

Keywords: AZ80A Mg alloy, friction-stir welding, tool rotational speed, residual stresses, fracture surfaces
\end{abstract}

Avtorji prispevka so ravne plošče iz Mg zlitine AZ80A med seboj varili s postopkom vrtilno-tornega varjenja. Pri tem so uporabili različne hitrosti vrtenja orodja in opazili, da je za porazdelitev v obliki črke M značilna porazdelitev zaostalih napetosti v vzdolžni smeri. Razen tega so ugotovili, da je vzdolžna napetost (natezna) na strani pomikanja orodja (AS; angl: advancing side) večja kot na nasprotni strani (RS; angl.: retreating side) v coni mešanja. Eksperimentalno so zaznali rahlo povečanje napetosti (vzdolžne natezne zaostale), povečanje hitrosti vrtenja orodja in povečanje konice natezne vzdolžne napetosti na robu držala pri AS zvara. Na strukturo kristalnih zrn v coni mešanja je vplivala hitrost vrtenja orodja. Opazovanje prelomnih površin varnjenih spojev je pokazalo, da so jamice in grebeni značilni za duktilni lom, kvazi cepilne površine pa za krhki lom.

Ključne besede: Mg zlitina AZ80A, vrtilno-torno varjenje, hitrost vrtenja orodja, zaostale napetosti, lomne površine

\section{INTRODUCTION}

Alloys of magnesium ( $\mathrm{Mg}$ ) included in the lightweight-metal group find wide applications in the automotive sectors due to their particular characteristic features including low density values, sound castability, high levels of damping capacity, faster recycling, etc. ${ }^{1}$ At the same time, manufacturing complicated parts using $\mathrm{Mg}$ alloys is still a challenging task, due to their closely packed hexagonal structural arrangement, which requires effective joining techniques. ${ }^{2}$ Traditional joining (fusion) techniques were found to result in various defects including cracks, pores and deterioration of the mechanical properties when employed for welding $\mathrm{Mg}$ alloys. ${ }^{3}$

In the past years, the technology of friction-stir welding (FSW) was found to produce weldments completely free from various irregularities, especially in the cases of metals with low fusion weldability features. ${ }^{4}$
FSW is an innovative, eco-friendly joining technique, in which weldments are produced successfully even before the melting of the parent metal takes place. This FSW technique involves the employment of a tool (non-consumable in nature) with a shoulder and uniquely designed pin geometry, piercing and plunging the surfaces of a workpiece, traversing along the line of a weld, thereby generating frictional heat, followed by plastic deformation, thereby producing a defect-free solid-state weldment. ${ }^{5}$

Various parameters of the FSW process including speed of rotation (tool), force in the axial direction, traverse speed, tool-pin profile etc. are found to play major roles in determining the quality of the weldments, ${ }^{6}$ thereby creating an essential need for controlling them to produce high-quality joints. Therefore, diverse and extensive experimental works ${ }^{7-11}$ concentrating on controlling these FSW process parameters in an effective 
manner and understanding the levels of influence of these parameters in determining the properties of joints were carried out.

For instance, Elangovan et al. ${ }^{7}$ conducted investigations to understand the impact of the tool-pin geometry in generating the FSW zone during the joining of aluminium alloys and proved that the usage of the tool with a square-pin geometry resulted in producing weldments with larger values of hardness and mechanical strength associated with very fine sized grains in the weldment nugget zone. Likewise, the effects of the depth of plunge, diameter of tool shoulder, speed of welding etc. on the internal-defect formation were investigated in a detailed manner by Ramulu et al. ${ }^{9}$ during the FSW of $6061 \mathrm{Al}$-alloy sheets. It was proved through experimental analysis that higher speeds of rotation (tool) and deep depths of the plunge should be preferred for producing defect-free weldments.

Experimental investigations concentrating on the impact of the axial force in determining the quality of the joints were also carried out. For example, an endeavour was made by Balasubramanian et al. ${ }^{11}$ to perceive the axial force's impact in the formation of the nugget zone during the FSW of Al-alloy (6061 alloy). Three entirely disparate values of forces (axially applied) were applied during the joining of 6061 plates and five distinct pin-profiled tools were employed in this experiment. The
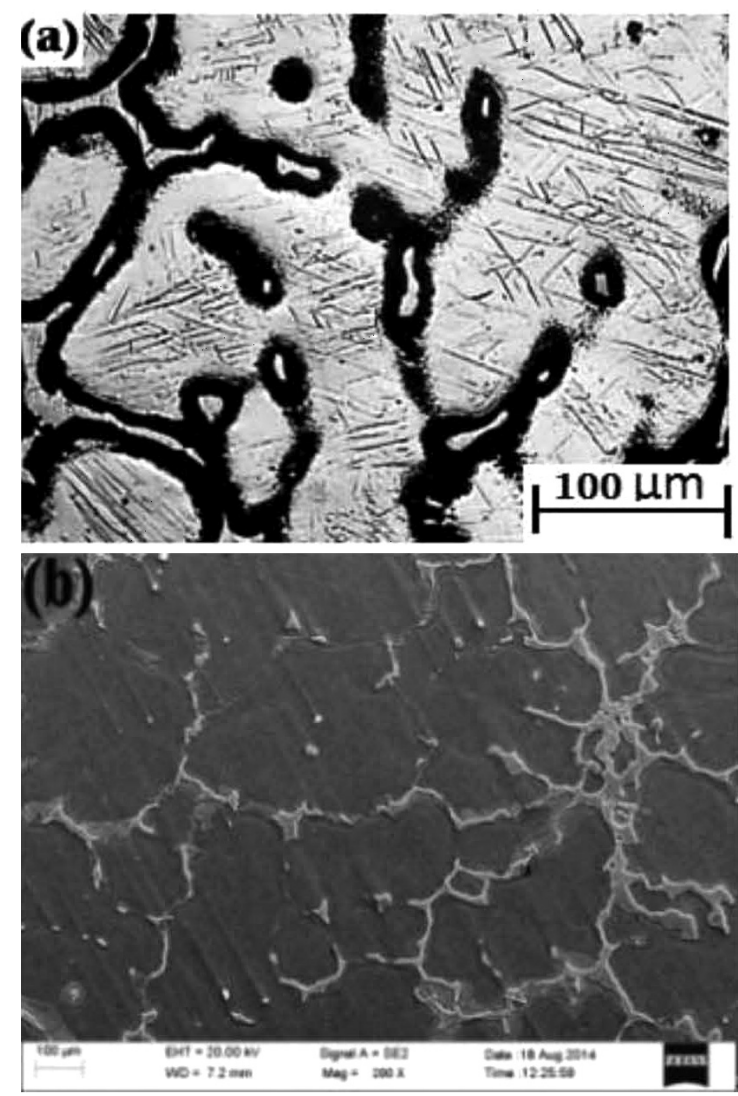

Figure 1: a) AZ80A Mg alloy - optical micrograph image and b) AZ80A Mg alloy - SEM image stir zone developed in the fabricated joints was subjected to various tests and analysed completely. This work recorded the observation that the joints fabricated while applying a 7-kN axial load (and using a FSW tool with a square-shaped pin) exhibited improved mechanical properties, together with the presence of finely dispersed grains in the nugget zone, when compared with those of the other joints fabricated at the remaining two disparate force values.

At the same time, it should be recorded that the majority of these investigations were carried out during the FSW of aluminium alloys and limited researches were carried out with respect to $\mathrm{Mg}$-alloys during the FSW process. It can be understood that these various recorded experimental investigations took into account the tool-pin geometry, axial force, etc. as their parameters of observation. Hence, there is an unavoidable necessity for investigating the impact of the speed of rotation of the FSW tools in determining the quality of weldments. In this paper, an experimental work is reported, carried out to investigate and understand the effect of the speed of rotation of the FSW tool on the microstructural evolution characteristics and the tensile properties of AZ80A Mg-alloy joints. Apart from achieving this basic objective, the experimental research also tried to provide an insight into the importance of optimized process parameters, suitable for fabricating high-quality dissimilar Mg-alloy joints using the FSW process.

\section{EXPERIMENTAL PART}

\subsection{Base-metal composition}

The AZ80A Mg-alloy in the extruded-plate form is taken as the metal of investigation in this work, having a thickness of $5 \mathrm{~mm}$, a width of $50 \mathrm{~mm}$ and a length of 100 $\mathrm{mm}$. The chemical composition of the base metal, namely the AZ80A Mg-alloy, was as follows: $8.87 \%$ of aluminium; $0.08 \%$ of silicon; $0.67 \%$ of zinc; $0.02 \%$ of copper; at $0.28 \%$ of manganese; less than $0.005 \%$ of nickel and iron together; and the remaining amount being magnesium. Apart from this, the tensile strength of the base metal was $290 \mathrm{MPa}$, the yield strength was $193 \mathrm{MPa}$ and the elongation was around $8.9 \%$. Figures 1a and $\mathbf{1 b}$ show, with a micrograph and a SEM (scanning electron microscope) image, the base metal (the AZ80A $\mathrm{Mg}$-alloy). It can be understood from these images that the base metal has a structure of coarse, unevenly distributed grains, associated with a notable volume of subgrains.

\subsection{Parameters of the FSW process}

An indigenously designed and fabricated semi-automatic FSW machine equipped with a 10-HP motor, as shown in Figure 2a, was employed in this investigation to fabricate AZ80A Mg-alloy joints. The tool used in this 

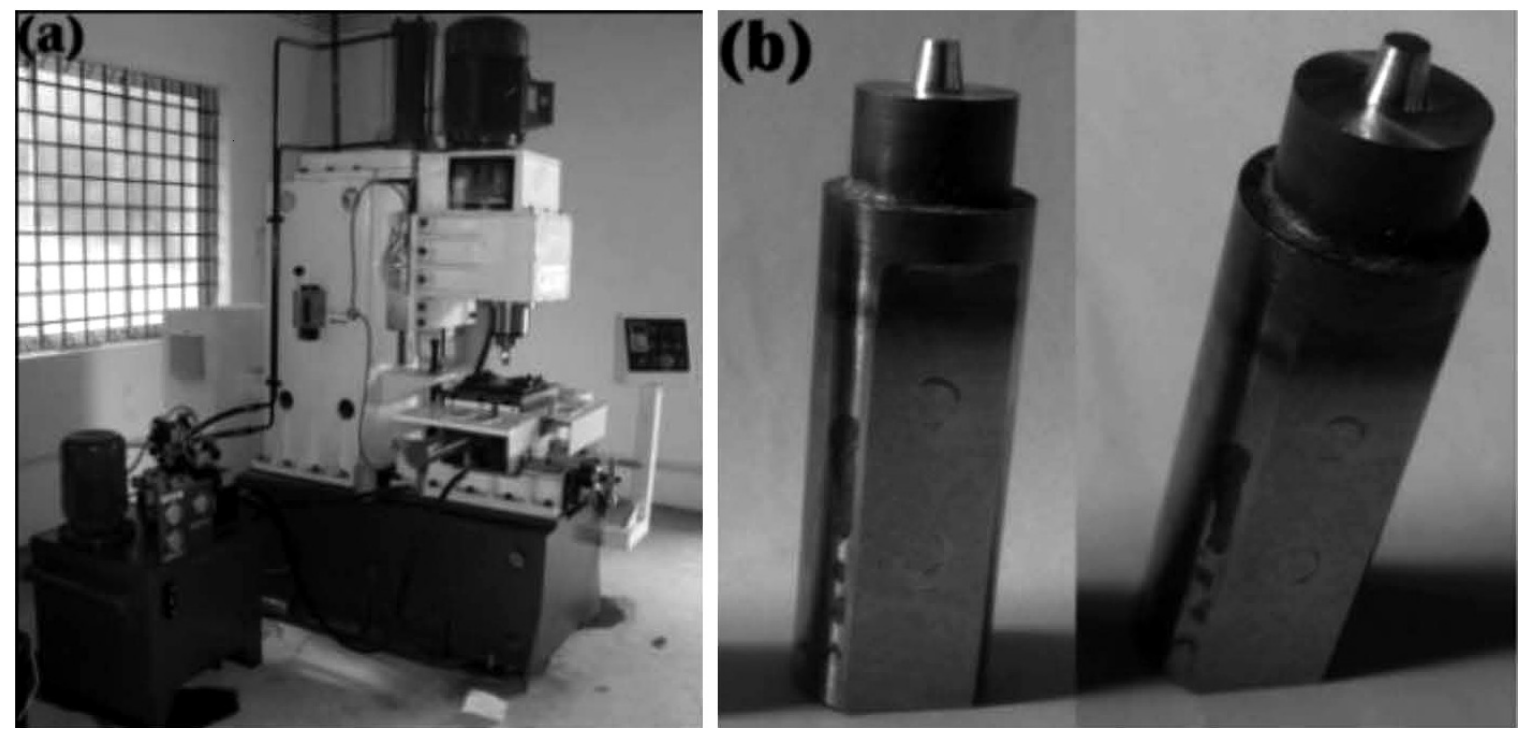

Figure 2: a) Photograph of the semi-automatic FSW machine and b) different views of HSS tool-pin geometry used in this work

work was fabricated from a HSS (high-speed steel) material, belonging to grade M35. The pin profile of the FSW tool employed had a cylindrical (tapered) profile. This FSW tool had a 12-mm shoulder diameter and a 4.8-mm depth of plunge. The major pin diameter was 7.5 $\mathrm{mm}$, tapering down to $4.5 \mathrm{~mm}$ as seen in Figure $2 \mathbf{b}$.

A complete set of AZ80A Mg-alloy joints was fabricated using the above-mentioned FSW tool at a uniform speed (traverse) of $75 \mathrm{~mm} / \mathrm{min}$ and a $3-\mathrm{kN}$ axial force, generated uniformly and continuously by the power motor. Since the main aim of this work was to understand the role of the tool rotational speed, influencing various features of the friction-stir-welded AZ80A Mg-alloy joints, three different values of the tool rotational speed including (500, 750 and 1000) $\mathrm{min}^{-1}$ were employed to fabricate the joints.

\section{RESULTS AND DISCUSSION}

\subsection{Macrostructural morphology}

The surfaces of the weldments fabricated using the FSW process at the rotational speeds ranging from 500-1000 $\mathrm{min}^{-1}$ are illustrated in Table 1. Abbreviations RS (retreating side) and AS (advancing side) indicate the side of retreatment and side of advancement of the joints fabricated using the FSW technique. It can be observed from this table that the joint fabricated at the speed of $500 \mathrm{~min}^{-1}$ was found to have a welding defect, namely a pin hole at the bottom of its RS and the occurrence of this large-size pin hole reveals that the tool rotational speed did not produce the frictional heat required, leading to poor plastic deformation. Likewise, we can also observe a tunnel defect in the lower region of the AS of the weldment fabricated at $1000 \mathrm{~min}^{-1}$. This sample reveals that this speed of the tool rotation

Table 1: Macrostructural morphology of the joints fabricated using FSW process

\begin{tabular}{|c|c|c|c|c|}
\hline Sample no. & $\begin{array}{l}\text { Speed of rotation of } \\
\text { FSW tool, } \mathrm{min}^{-1}\end{array}$ & $\begin{array}{l}\text { Appearance of the } \\
\text { weldments }\end{array}$ & $\begin{array}{c}\text { Weldment } \\
\text { macrostructure } \\
\text { RS AS }\end{array}$ & Observation \\
\hline 1 & 500 & & & $\begin{array}{l}\text { RS with a pin hole in the } \\
\text { bottom part }\end{array}$ \\
\hline 2 & 750 & & & Defect-free joint \\
\hline 3 & 1000 & $(x+1)(j)$ & & $\begin{array}{l}\text { AS with a tunnel defect in the } \\
\text { bottom part }\end{array}$ \\
\hline
\end{tabular}



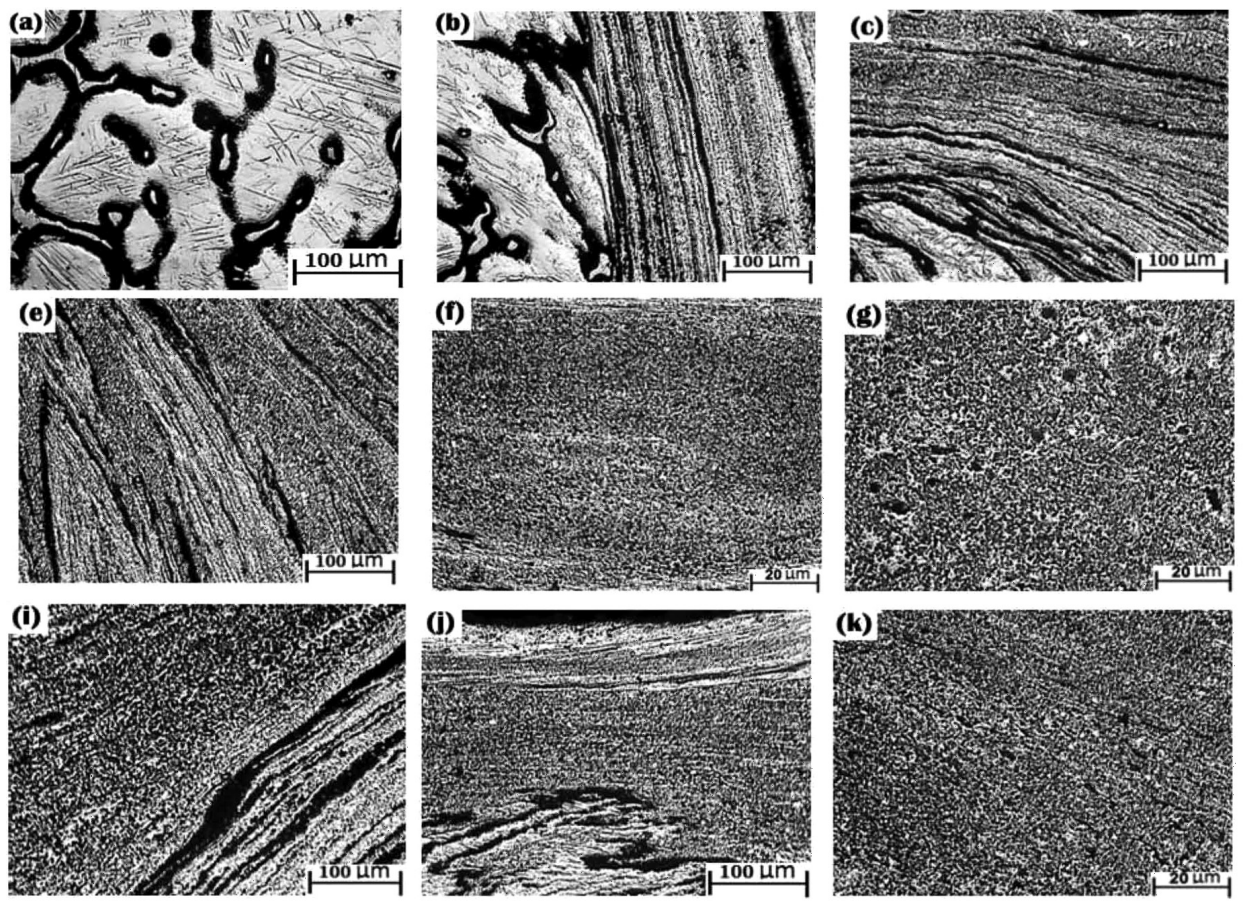

Figure 3: Microstructural images of defect-free weldment (sample no. 2): a) base metal, b) interface zone near AS, c) SZ influenced by the surface of FSW tool, d) SZ, e) TMAZ, f) centre of SZ, g) magnified image of SZ, h) interface of SZ and TMAZ, i) lower region of interface of SZ and TMAZ, j) interface zone near RS, k) SZ at $100 \times$, l) SZ at 200×

generated an excessive amount of frictional heat that led to an improper flow of the plasticized material resulting in a tunnel defect. At the same time, the macrostructure of the AZ80A Mg-alloy joint fabricated at $750 \mathrm{~min}^{-1}$ is found to be completely free from defects, revealing the fact that employing the tool at a proper speed generates sufficient amount of frictional heat for an adequate and proper flow of the plasticized material both on the RS and AS of the weldment. These experimental observations confirm that the rotational speed of the FSW tool plays a crucial role in determining macrostructural morphology.

\subsection{Characterization of the joint microstructure}

Microstructures of different zones of friction-stirwelded AZ80A Mg-alloy sample no. 2 (i.e., the defectfree joint produced at $750 \mathrm{~min}^{-1}$ ) including the stir zone (SZ), heat-affected zone (HAZ) and thermomechanically affected zone (TMAZ) are clearly illustrated in Figure 3.

By comparing the optical-microscopy photographs of different zones of the defect-free joint (Figure $\mathbf{3 b}-$ to 31) with the photograph of the base metal shown in Figure 3a, it can be easily understood that the stirring action of the FSW technique resulted in a transformation process, during which the non-uniformly scattered coarse grains with massive $\mathrm{Al}_{12} \mathrm{Mg}_{17}$ precipitates were completely reconstructed into uniformly disbursed, unique, small-sized grain structures, especially in the NZ of the fabricated joint. For instance, the interface zone at the AS is illustrated in Figure 3b. In this image, the parent metal's grain structure is on the left side and the SZ is on the right side. It can be noticed that recrystallization of the particles started due to the employment of the optimal tool speed, which generated the stress and temperature suitable for creating a uniform metal flow in the SZ. The stir-zone microstructure together with the formation of grains (due to the dynamic stirring action of the rotating tool) is seen in Figure $\mathbf{3 g}$.

This SZ image helps us understand that the defectfree joint formation is the effect of the uniformly scattered, fine-sized, equally sized grains. Figures $\mathbf{4 a}$ to 4c show and compare, in detail, the stir zones of the joints fabricated at $500 \mathrm{~min}^{-1}, 750 \mathrm{~min}^{-1}$ and $1000 \mathrm{~min}^{-1}$ (i.e., samples nos. 1-3). By studying these images, we can observe that all the three samples have different grain sizes and grain distributions. For example, the SZ of sample no. 1 (Figure 4a) is found to have larger grains when compared with the other joints. Thus, the samples can be ranked in the following order based on the size of the grains in the SZ: sample no. $2<$ sample no. 3 < sample no. 1 .

Moreover, the SZ of sample no. 2 (i.e., the joint fabricated at $750 \mathrm{~min}^{-1}$ ) is found to have very fine grains, which are equally and uniformly distributed in a homogeneous manner throughout the entire SZ. This feature contributed directly to the generation of high-quality weldments, which are found to be completely free from defects. Thus, the presence of a variable size of the grains in the SZs of the joints obtained at three different speeds of the tool rotation helps us understand that the tool rotational speed plays a significant role, influencing 

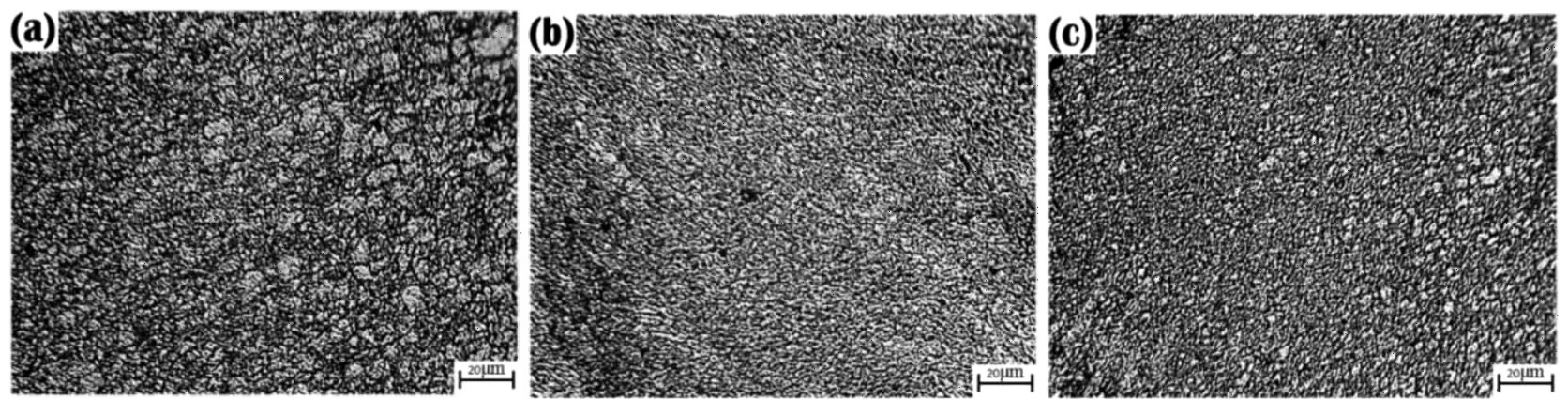

Figure 4: Microstructure images of the stir zone generated at: a) $500 \mathrm{~min}^{-1}$, b) $750 \mathrm{~min}^{-1}$ and c) $1000 \mathrm{~min}^{-1}$

the grain size and distribution of the grains in the stir zone.

\subsection{Analysis of the residual stress}

In this investigative work, the stresses (residual) of the joints fabricated using the FSW process were determined and calculated using the methodology of drilling a hole. In the joint samples, stable values of stresses (residual) were found in the centre region of the friction-stir-welded portion and the distribution of stresses (residual) in these centre regions are considered to exemplify the stress (residual) distribution for the entire region of the fabricated joints. ${ }^{12}$ Figure 5a illustrates the locations of various points of measurement related to the measurement of the residual stresses and also the points of residual-stress measurements within the portion of $\mathrm{Y}=10-90 \mathrm{~mm}$. The measurements of the transverse and longitudinal residual stress along the surfaces of the joints fabricated during the FSW process are illustrated in Figures $\mathbf{5 b}$ and $\mathbf{5 c}$. We can observe that, as shown in
Figure 5b, the distributions of the residual stress (longitudinal) seems to follow an M-shaped dissemination, followed by a little asymmetry in the regions of higher stress, which resulted from the generation of higher values of the tensile stress on the AS when compared with the stress values on the RS. In most cases, the larger values of the stresses occurred in the zones falling within $\mathrm{Y}=45-65 \mathrm{~mm}$, directly corresponding to the shoulder diameter of the FSW tool. Beyond the regions of the tool-shoulder diameter, there seems to be an immediate decline in the residual stress followed by a transformation into the compressive residual stress. Further, this residual stress is found to rise with the simultaneous increase in the speed of rotation of the FSW tool and the maximum values of the longitudinal tensile residual stress for the three different joint samples include (160, 153 and 148) MPa.

At the same time, the residual stresses in the transverse direction are found to be smaller when compared with the longitudinal stresses and these transverse stresses are found not to follow any direct level of

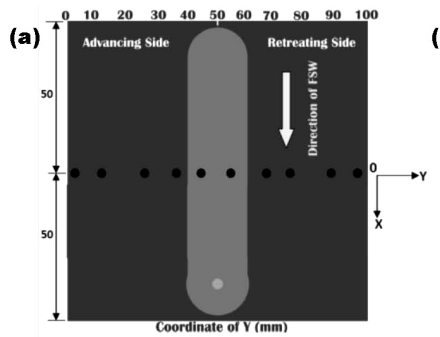

(b)

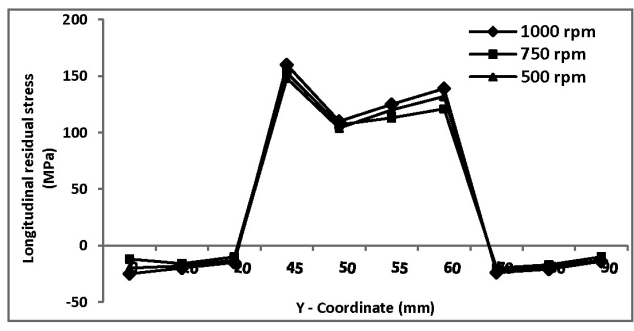

(c)

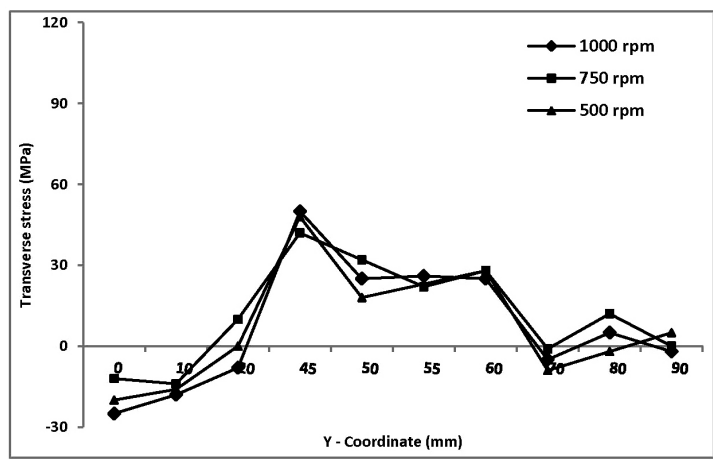

Figure 5: Graphical illustration of the distribution of: a) various points of measurement related to the measurement of the residual stresses and also the points of residual-stress measurements within the portion of $\mathrm{Y}=10-90 \mathrm{~mm}, \mathrm{~b}$ ) longitudinal and c) transverse residual stresses 
dependence w.r.t. the speed of rotation of the FSW tool. The maximum values of the longitudinal tensile residual stresses for the three different joint samples include (50, 42 and 48) $\mathrm{MPa}$, respectively. In this experimental work, the graphical profile of the residual stresses indicates that the longitudinal tensile residual stresses are found to increase gradually with the raise in the speed of rotation of the FSW tool. This phenomenon occurs due to the temperature variation in the FSW zones. $^{13}$ In other words, increasing the tool rotational speed eventually leads to an increase in the temperature, creating higher values of the thermal residual-stress gradient leading to a direct increase in the residual stresses in the joint area. Apart from this, the raise in the rotational speed also leads to an increase in the volume of the forward forces (in the stir zone), even before the softening of the parent metal occurs. These forward forces result in the generation of an adequate amount of higher values of residual stresses.

Since all the above-mentioned phenomena occur along the tool-shoulder contact area, the remaining portions of the base metal are not found to undergo any changes arising from the stirring force (generated by the tool-pin rotation). It is proven that the variations in the stresses (residual) are mainly due to the changes taking place in the microstructures. ${ }^{14}$ So, it can be understood that with the raise in the speed of the rotation of the FSW tool, the longitudinal residual stresses (tensile) increase only slightly, not remarkably.

\subsection{Tensile strength and a fractography analysis}

The impact of the influence of the speed of rotation of the FSW tool on the tensile strength of the joints fabricated using the FSW process is illustrated in Figure 6a. It can be seen that the tensile strength reaches its highest value when the rotational speed increases from $500 \mathrm{~min}^{-1}$ to $750 \mathrm{~min}^{-1}$ and then decreases when the
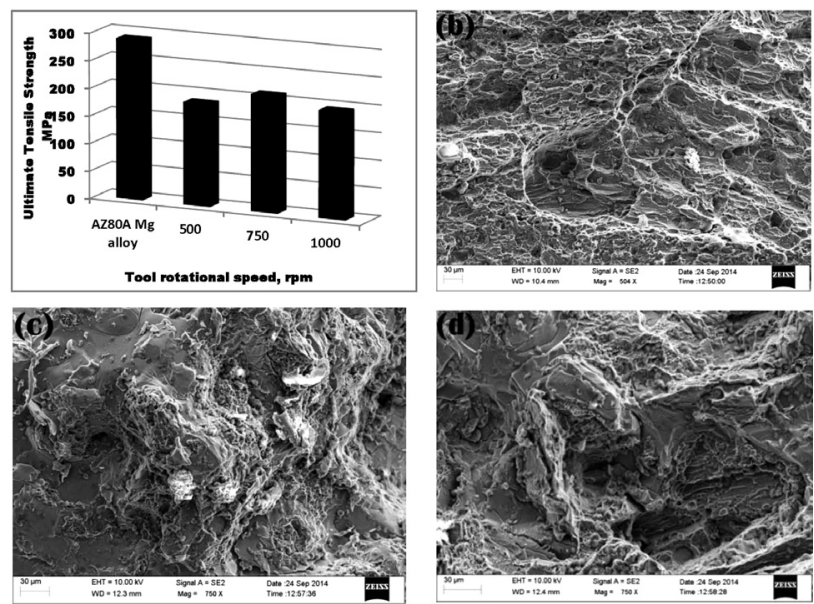

Figure 6: a) Graphical illustration of the effect of the tool rotational speed on the tensile strength of the FSW joints; fractographic SEM images of the fractured specimens produced at b) $500 \mathrm{~min}^{-1}$ c) 750 $\mathrm{min}^{-1}$ and d) $1000 \mathrm{~min}^{-1}$ speed is raised to $1000 \mathrm{~min}^{-1}$. It should be recorded that the tensile-strength values for the joints of Sample nos. 1, 2 and 3 are (186, 212 and 195) MPa, respectively. This indicates that the highest value of the tensile strength of the fabricated joints is reached at the rotational speed of $750 \mathrm{~min}^{-1}$ and it accounts for nearly $73 \%$ of the strength of the parent metal. One important reason for the above-mentioned tensile-strength values is that the larger input of heat values (arising due to higher values of the rotational speed) must have resulted in the increase of the grain size followed by a simultaneous disintegration of the massive intermetallic $\mathrm{Al}_{12} \mathrm{Mg}_{17}$ precipitates in the AZ80A Mg FSW zone. ${ }^{15,16}$ Apart from this, it is already proven that higher tool-rotational speeds result in an enormous amount of heat input, which immediately leads to an uncontrollable turbulence of the plasticized materials in the FSW zone and eventually results in the generation of defects in the joints. ${ }^{17}$ Hence, it can be summarized that the increase in the speed of rotation of the FSW tool initially results in an increase in the tensile strength, eventually declining with further increase in the rotational speed.

It is a proven fact that the fracture of a tensile specimen takes place due to the residual stress or localized strains. Various changes are found to occur in the microstructures, distribution of secondary-phase particles and welding stresses (residual) due to different levels and volumes of the material flow caused by different speeds of rotation of the FSW tool. ${ }^{18,19}$ This leads to the fabrication of joints with different tensile strengths. In order to figure out the manner, in which the failure of a tensile specimen took place, various tensile-fractured joints fabricated at different rotational speeds of the FSW tool (i.e., at $500 \mathrm{~min}^{-1}, 750 \mathrm{~min}^{-1}$ and $1000 \mathrm{~min}^{-1}$ ) are subjected to an analysis using the SEM (scanning electron microscopic) methodology and the corresponding SEM micrographs are shown in Figures $6 \mathbf{b}$ to $\mathbf{6 d}$.

By observing these SEM images, we can clearly understand that the joints fabricated at $750 \mathrm{~min}^{-1}$ underwent a failure in the ductile mode (Figure 6c). It can be seen on Figure 6c that this surface (after the fracture) contains tearing ridges and various dimples (which are small and of different sizes). This proves that the failure took place in the ductile mode..$^{20}$ This mode of failure always occurs when there is a uniform flow of a plasticized material in the stir zone. This uniform flow directly contributes to the generation of defect-free joints. ${ }^{21}$ Apart from this, we can notice on Figures $\mathbf{6 b}$ and 6d that these SEM images (of the joints with samples nos. 1 and 3) exhibit fractured surfaces covered with a lot of cleavage structures (in a quasi-manner) and with various layered edges, which indirectly helps us understand that the fracture of these tensile specimens occurred in the brittle mode of failure. 


\section{CONCLUSIONS}

In this experimental investigation, the joining of AZ80A Mg-alloy flat plates was carried out using the FSW process at three different rotational speeds including (500, 750 and 1000) $\mathrm{min}^{-1}$. The major experimental results obtained are as follows:

Defect-free weldments were obtained at a tool rotational speed of $750 \mathrm{~min}^{-1}$ and a constant traverse speed of $75 \mathrm{~mm} / \mathrm{min}$ while applying a $3-\mathrm{kN}$ axial force to the FSW tool with a taper cylindrical profile.

The size of the grains in the stir zone was found to be significantly influenced by the speed of rotation of the FSW tool and the SZs of the joints fabricated at 750 $\mathrm{min}^{-1}$ were found to have uniformly distributed, equally spaced fine-sized grains, contributing, in turn, to the fabrication of defect-free joints.

Based on the size of the grains in the SZ, the samples were ranked in the following order: sample no. $2<$ sample no. $3<$ sample no. 1 .

The profiles of the residual (longitudinal) stresses exhibited an M-shaped distribution in the transverse direction. The tensile residual (longitudinal) stress was found to increase gradually with the raise in the rotational speed, and a higher residual stress occurred at the tool-shoulder edge along the AS of a weldment.

The tensile strength did not exhibit any appreciable proportional response w.r.t. the rotational speed of the FSW tool. The maximum value of the tensile strength (73\% of the strength of the base metal) was exhibited by the weldments fabricated at $750 \mathrm{~min}^{-1}$.

The SEM fractographic analysis revealed that the fracture of the joints with sample no. 2 took place in the ductile mode, which was identified due to the presence of tearing ridges and micro-dimples. This fracture indirectly shows that there was a uniform flow of the plasticized material in the SZs of these weldments.

Additionally, this paper provides the scope for conducting experimental investigations to understand the impacts of the other FSW process parameters like the force in the axial direction, traverse speed, tool-pin profile, etc. in determining the quality of the weldments during the FSW of various types of dissimilar Mg-alloys. Conducting experiments and comparing the results of these observations will help us determine the optimized process parameters suitable for fabricating high-quality dissimilar Mg-alloy joints using the FSW process.

\section{ACKNOWLEDGEMENT}

The authors very sincerely acknowledge the S.A. Engineering College's Mechanical Department and its Management for granting us the permission to make use of the FSW equipment and other devices. The authors also express their sincere gratitude to the AICTE (All India Council for Technical Education), India, for sanctioning the funded project with grant no.
8023/RID/RPS/037/2011-12 (for acquiring an FSW machine).

\section{REFERENCES}

${ }^{1}$ X. Cao, M. Jahazi, Effect of tool rotational speed and probe length on lap joint quality of a friction stir welded magnesium alloy, Materials and Design, 32 (2011), 1-11, doi:10.1007/s00170016-9741-7

${ }^{2}$ H. S. Arora, H. Singh, B. K. Dhindaw, Wear behaviour of a Mg alloy subjected to friction stir processing, Wear, 303 (2013), 65-77, doi:10.1007/s 11665-013-0786-6

${ }^{3}$ R. K. Kesharwani, S. K. Panda, S. K. Pal, Multi-Objective Optimization of friction stir welding parameters for joining of two dissimilar thin aluminum sheets, Procedia Materials Science, 6 (2014), 178-187, doi:10.1016/j.mspro.2014.07.022

${ }^{4} \mathrm{P}$. Sevvel, V. Jaiganesh, Influence of the arrangement of materials and microstructural analysis during FSW of AZ80A \& AZ91C Mg alloys, Archives of Metallurgy and Materials, 62 (2017) 3, 1795-1801, doi:10.1515/amm-2017-0270

${ }^{5}$ D. G. Hattingh, C. Blignault, T. I. van Niekerk, M. N. James, Characterization of the influences of FSW tool geometry on welding forces and weld tensile strength using an instrumented tool, Journal of Materials Processing Technology, 203 (2008) 1-3, 46-57, doi:10.1016/j.jmatprotec.2007.10.028

${ }^{6} \mathrm{~V}$. Jaiganesh, P. Sevvel, Effect of process parameters on the microstructural characteristics and mechanical properties of AZ80A $\mathrm{Mg}$ alloy during friction stir welding, Transactions of the Indian Institute of Metals, 68 (2015) 1, 99-104, doi:10.1007/s12666015-0620-y

${ }^{7}$ K. Elangovan, V. Balasubramanian, Influences of tool pin profile and welding speed on the formation of friction stir processing zone in AA2219 aluminium alloy, Journal of Materials Processing Technology, 200 (2008), 163-175, doi:10.1016/j.jmatprotec. 2007.09.019

${ }^{8}$ G. Padmanaban, V. Balasubramanian, An experimental investigation on friction stir welding of AZ31B magnesium alloy, International Journal of Advanced Manufacturing Technology, 49 (2010), 111-121, doi:10.1007/s00170-009-2368-1

${ }^{9}$ P. J. Ramulu, R. G. Narayanan, S. V. Kailas, J. Reddy, Internal defect and process parameter analysis during friction stir welding of $\mathrm{Al}$ 6061 sheets, International Journal of Advanced Manufacturing Technology, 65 (2013), 1515-1528, doi:10.1007/s00170-012-4276-z

${ }^{10}$ V. Jain, R. S. Mishra, A. K. Gupta, Study of $\beta$-precipitates and their effect on the directional yield asymmetry of friction stir processed and aged AZ91C alloy, Material Science and Engineering A, 560 (2013), 500-509, doi:10.1016/j.msea.2012.09.095

${ }^{11}$ K. Elangovan, V. Balasubramanian, M. Valliappan, Influences of tool pin profile and axial force on the formation of friction stir processing zone in AA6061 aluminium alloy, International Journal of Advanced Manufacturing Technology, 38 (2008), 285-295, doi:10.1007/ s00170-007-1100-2

${ }^{12}$ G. M. Xie, Z. Y. Ma, L. Geng, Effect of microstructural evolution on mechanical properties of friction stir welded ZK60 alloy, Materials Science and Engineering A, 486 (2008), 49-55, doi:10.1016/j.msea. 2007.08.043

${ }^{13}$ A. Razal Rose, K. Manisekar, V. Balasubramanian, Effect of axial force on microstructure and tensile properties of friction stir welded AZ61A magnesium alloy, Transactions of Nonferrous Metals Society of China, 21 (2011) 5, 974-984, doi:10.1016/S1003-6326(11) 60809-1

${ }^{14}$ J. F. Jiang, X. Lin, Y. Wang, J. J. Qu, S. J. Luo, Microstructural evolution of AZ61 magnesium alloy predeformed by ECAE during semisolid isothermal treatment, Transactions of Nonferrous Metals Society of China, 22 (2012) 3, 555-563, doi:10.1016/S10036326(11)61213-2 


\section{P. SEVVEL, C. SATHEESH: ROLE OF TOOL ROTATIONAL SPEED IN INFLUENCING MICROSTRUCTURAL ...}

${ }^{15} \mathrm{P}$. Sevvel, V. Jaiganesh, Impact of process parameters during friction stir welding of AZ80A Mg alloy, Science and Technology of Welding and Joining, 21 (2016) 2, 83-90, doi:10.1179/ $1362171815 \mathrm{Y} / 0000000068$

${ }^{16} \mathrm{~S}$. Rajakumar, V. Balasubramanian, A. Razalrose, Friction stir and pulsed current gas metal arc welding of AZ61A magnesium alloy: A comparative study, Materials and Design, 49 (2013), 267-278, doi:10.1016/j.matdes.2013.01.051

${ }^{17} \mathrm{M}$. Erdem, Investigation of structure and mechanical properties of copper-brass plates joined by friction stir welding, International Journal of Advanced Manufacturing Technology, 76 (2015) 9, 1583-1592, doi:10.1007/s00170-014-6387-1

${ }^{18}$ M. S. Moghaddam, R. Parvizi, M. Haddad-Sabzevar, A. Davoodi, Microstructural and mechanical properties of friction stir welded $\mathrm{Cu}-30 \mathrm{Zn}$ brass alloy at various feed speeds: influence of stir bands, Materials and Design, 32 (2011), 2749-2755, doi:10.1016/j.matdes. 2011.01.015
${ }^{19}$ R. Zeng, W. Dietzel, R. Zettler, J. Chen, K. U. Kainer, Microstructure evolution and tensile properties of friction-stir-welded AM50 magnesium alloy, Transactions of Nonferrous Metals Society of China, 18 (2008), S76-S80, doi:10.1016/S1003-6326(10)60178-1

${ }^{20} \mathrm{C}$. B. Jagadeesha, Dissimilar friction stir welding between aluminum alloy and magnesium alloy at a low rotational speed, Materials Science and Engineering A, 616 (2014), 55-62, doi:10.1016/ j.msea.2014.07.090

${ }^{21}$ D. Liu, R. Xin, L. Sun, Z. Zhou, Q. Liu, Influence of sampling design on tensile properties and fracture behavior of friction stir welded magnesium alloys, Materials Science and Engineering A, 576 (2013), 207-216, doi:10.1016/j.msea.2013.03.037 